\title{
Kejadian Ikutan Pasca Imunisasi
}

\author{
Sri Rezeki S. Hadinegoro
}

\begin{abstract}
Dalam era globalisasi, imunisasi merupakan upaya pencegahan penyakit infeksi menuju masa depan anak yang lebih sehat. Peningkatan pemberian imunisasi harus diikuti dengan peningkatan efektifitas dan keamanan vaksin. Walaupun demikian, peningkatan penggunaan vaksin akan meningkatkan pula kejadian ikutan pasca imunisasi (KIPI) yang tidak diinginkan. Guna mengetahui apakah KIPI yang terjadi disebabkan oleh imunisasi, maka diperlukan pelaporan pencatatan dari semua reaksi yang timbul setelah pemberian imunisasi. Reaksi KIPI dapat dipantau melalui sistim surveilans yang baik untuk mendapatkan profil keamanan penggunaan vaksin di lapangan. Untuk mengetahui besaran masalah KIPI di Indonesia diperlukan pelaporan dan pencatatan KIPI dan koordinasi antara pengambil keputusan dengan petugas pelaksana di lapangan, guna menentukan sikap dalam mengatasi KIPI yang terjadi. Diharapkan surveilans KIPI dapat membantu program imunisasi, khususnya untuk memperkuat keyakinan masyarakat akan pentingnya imunisasi sebagai upaya pencegahan penyakit yang paling efektif.
\end{abstract}

Kata kunci: KIPI - Surveilans - Kelompok kerja (Pokja) KIPI

$\mathcal{T}$

munisasi telah diakui sebagai upaya pencegahan suatu penyakit infeksi yang paling sempurna dan berdampak pada peningkatan kesehatan masyarakat. Oleh karena itu, kebutuhan akan vaksin makin meningkat seiring dengan keinginan dunia untuk mencegah berbagai penyakit yang dapat menimbulkan kecacatan dan kematian. Peningkatan kebutuhan vaksin telah ditunjang dengan upaya perbaikan dalam produksi vaksin guna meningkatkan efektifitas dan keamanan. ${ }^{1}$

Faktor terpenting yang harus dipertimbangkan dalam pembuatan vaksin adalah keseimbangan antara imunitas yang akan dicapai dengan reaksi yang tidak diinginkan yang mungkin timbul. ${ }^{2}$ Untuk mencapai imunogenisitas yang tinggi, vaksin harus berisi antigen yang efektif untuk merangsang respons imun

- Ketua Pokja KIPI Depkes RI.

- Telah dipresentasikan pada MUNAS IDI, Purwokerto 26 Nopember 1999

Alamat korespondensi:

DR. Dr. Sri Rezeki Hadinegoro,SpA(K)

Subbagian Infeksi \& Pediatri Tropis Bagian Ilmu Kesehatan Anak FKUI/ RSCM Jakarta, Jl. Salemba No. 6, Jakarta 10430, Indonesia.

Telpon: (021) 391 4126. Fax.: (021) 391 4126, e-mail: idaijaya@cbn.net.id protektif resipien dengan nilai antibodi di atas ambang pencegahan untuk jangka waktu yang cukup panjang. Sebaliknya antigen harus diupayakan mempunyai sifat reaktogenisitas yang rendah sehingga tidak menimbulkan efek samping yang berat, dan yang jauh lebih ringan apabila dibandingkan dengan komplikasi penyakit yang bersangkutan secara alami. Pada kenyataannya, tidak ada satu jenis vaksin pun yang sempurna. Namun dengan kemajuan di bidang bioteknologi saat ini telah dapat dibuat vaksin yang relatif efektif dan aman. ${ }^{3}$

Seiring dengan cakupan imunisasi yang tinggi, maka penggunaan vaksin juga meningkat sehingga reaksi vaksinasi yang tidak diinginkan juga meningkat. Hal yang penting dalam menghadapi reaksi vaksinasi yang tidak diinginkan ialah: Apakah kejadian tersebut berhubungan dengan vaksin yang diberikan? Ataukah bersamaan dengan penyakit lain yang telah diderita sebelum pemberian vaksin (koinsidensi)? ${ }^{4}$ Seringkali hal ini tidak dapat ditentukan dengan tepat sehingga oleh WHO digolongkan dalam kelompok adverse events following immunisation (AEFI) atau kejadian ikutan pasca imunisasi (KIPI).

Kejadian ikutan pasca imunisasi (KIPI) adalah 
suatu kejadian sakit yang terjadi setelah menerima imunisasi yang diduga disebabkan oleh imunisasi. ${ }^{3}$ Untuk mengetahui hubungan antara pemberian imunisasi dengan KIPI diperlukan pelaporan dan pencatatan semua reaksi yang tidak diinginkan yang timbul setelah pemberian imunisasi. Surveilans KIPI sangat membantu program imunisasi, khususnya untuk memperkuat keyakinan masyarakat akan pentingnya imunisasi sebagai upaya pencegahan penyakit yang paling efektif. Gejala dan tatalaksana serta pelaporan KIPI akan dibahas dalam makalah ini.

\section{Maturasi Program Imunisasi}

Telah terbukti bahwa pemberian imunisasi akan menurunkan insidens penyakit. Musnahnya penyakit cacar (variola) dari muka bumi sejak tahun 1980 merupakan contoh keberhasilan imunisasi terhadap kejadian penyakit cacar. Keberhasilan vaksinasi tersebut kemudian diikuti oleh pemakaian vaksin lain dalam dosis besar. Namun, di dalam perjalanan pemberian vaksin terdapat maturasi persepsi masyarakat sehubungan dengan reaksi yang tidak diinginkan akibat vaksinasi sehingga menyebabkan munculnya kembali penyakit dalam bentuk kejadian luar biasa (KLB). Chen ${ }^{4}$ membuat perkiraan perjalanan program imunisasi dihubungkan dengan maturasi kepercayaan masyarakat dan dampaknya pada insidens penyakit (Gambar 1).

1. Prevaksinasi. Pada saat ini insidens penyakit masih tinggi, imunisasi belum dilakukan sehingga KIPI belum menjadi masalah.

2. Cakupan meningkat. Pada fase ini, imunisasi telah menjadi program di suatu negara, maka makin lama cakupan makin meningkat yang berakibat penurunan insidens penyakit. Seiring dengan peningkatan cakupan imunisasi, terjadi peningkatan kasus KIPI di masyarakat.

3. Kepercayaan masyarakat (terhadap imunisasi) menurun. Peningkatan kasus KIPI mengancam kepercayaan masyarakat terhadap program imunisasi.

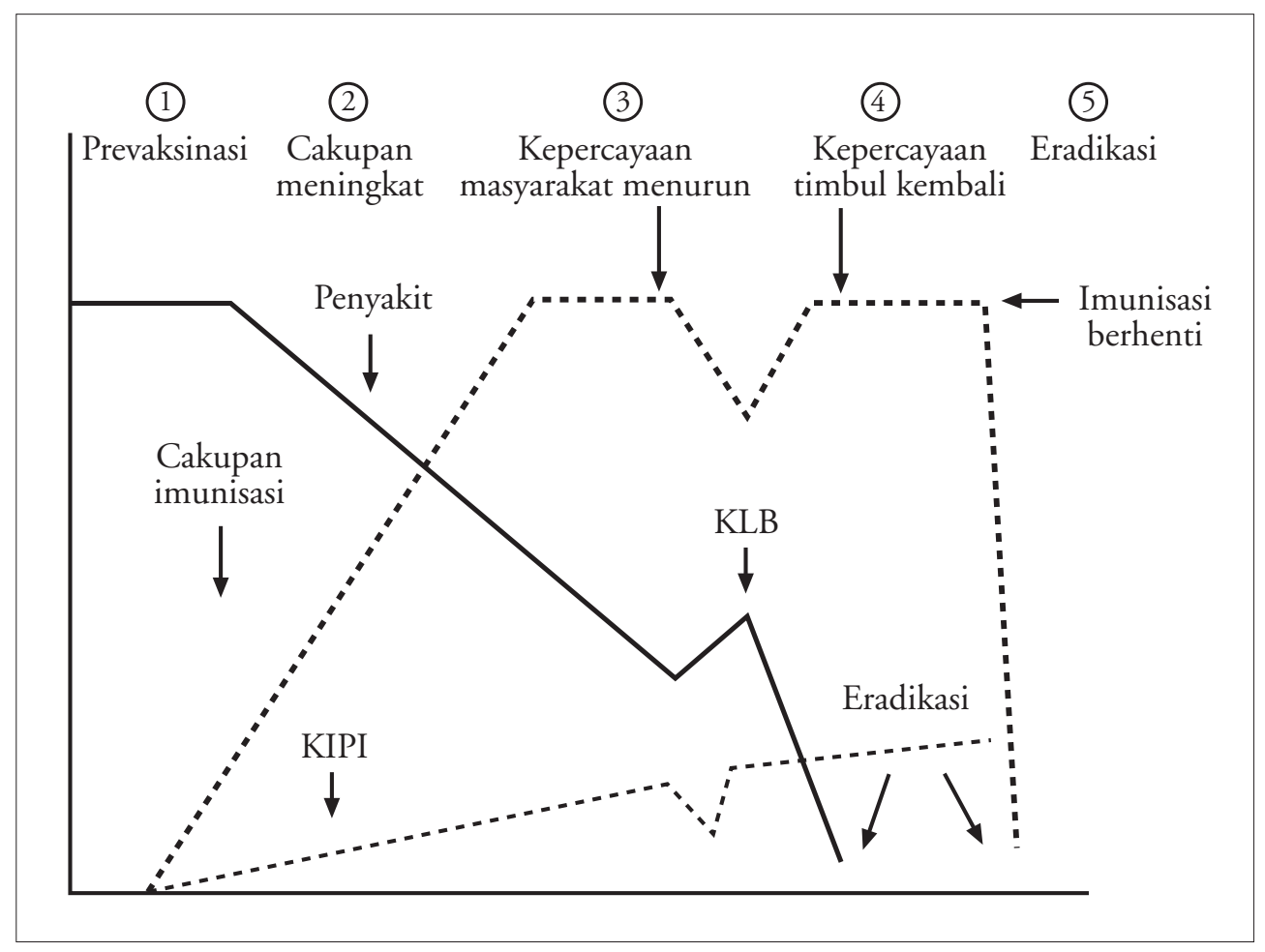

Gambar 1. Maturasi Program Imunisasi. Dikutip dari Chen RT. ${ }^{4}, 1999$ dengan modifikasi. 
Fase ini sangat berbahaya oleh karena akan menurunkan cakupan imunisasi. Walaupun kejadian KIPI tampak menurun tetapi berakibat meningkatnya kembali insidens penyakit sehingga terjadi kejadian luar biasa (KLB).

4. Kepercayaan masyarakat timbul kembali. Apabila kasus KIPI dapat diselesaikan dengan baik, yaitu dengan pelaporan dan pencatatan yang baik, penanganan kasus KIPI segera, dan pemberian ganti rugi yang memadai, maka kepercayaan masyarakat akan program imunisasi timbul kembali. Pada saat ini akan dicapai kembali cakupan imunisasi yang tinggi dan penurunan insidens penyakit; walaupun kasus KIPI tetap ada bahkan akan meningkat lagi.

5. Eradikasi. Hasil akhir program imunisasi adalah eradikasi suatu penyakit. Pada fase ini telah terjadi maturasi kepercayaan masyarakat terhadap imunisasi, walaupun kasus KIPI tetap dapat dijumpai.

\section{Klasifikasi KIPI}

Tidak semua kejadian KIPI yang diduga itu benar. Sebagian besar ternyata tidak ada hubungannya dengan imunisasi. Oleh karena itu untuk menentukan KIPI diperlukan keterangan mengenai berapa besar frekuensi kejadian KIPI pada pemberian vaksin tertentu; bagaimana sifat kelainan tersebut, lokal atau sistemik; bagaimana derajat kesakitan resipien, apakah memerlukan perawatan, apakah menyebabkan cacat, atau menyebabkan kematian; apakah penyebab dapat dipastikan, diduga, atau tidak terbukti; dan akhirnya apakah dapat disimpulkan bahwa KIPI berhubungan dengan vaksin, kesalahan produksi, atau kesalahan pemberian.

Berdasarkan data yang diperoleh, maka KIPI dapat diklasifikasikan dalam: ${ }^{5}$

1. Induksi vaksin (vaccine induced). Terjadinya KIPI disebabkan oleh karena faktor intrinsik vaksin terhadap individual resipien. Misalnya, seorang anak menderita poliomielitis setelah mendapat vaksin polio oral.

2. Provokasi vaksin (vaccine potentiated). Gejala klinis yang timbul dapat terjadi kapan saja, saat ini terjadi oleh karena provokasi vaksin. Contoh: Kejang demam pasca imunisasi yang terjadi pada anak yang mempunyai predisposisi kejang.

3. Kesalahan (pelaksanaan) program (programmatic errors). Gejala KIPI timbul sebagai akibat kesalahan pada teknik pembuatan dan pengadaan vaksin atau teknik cara pemberian. Contoh: terjadi indurasi pada bekas suntikan disebabkan vaksin yang seharusnya diberikan secara intramuskular diberikan secara subkutan.

4. Koinsidensi (coincidental). KIPI terjadi bersamaan dengan gejala penyakit lain yang sedang diderita. Contoh: Bayi yang menderita penyakit jantung bawaan mendadak sianosis setelah diimunisasi.

WHO pada tahun 1991, melalui Expanded Programme of Immunisation (EPI) telah menganjurkan pelaporan KIPI oleh tiap negara. Untuk negara berkembang yang paling penting adalah bagaimana mengkontrol vaksin dan mengurangi programmatic errors, termasuk cara penggunaan alat suntik dengan baik, alat sekali pakai atau alat suntik auto-distruct, dan cara penyuntikan yang benar sehingga transmisi patogen melalui darah dapat dihindarkan. Ditekankan pula bahwa untuk memperkecil terjadinya KIPI, harus senantiasa diupayakan peningkatan ketelitian, pada pemberian imunisasi selama program imunisasi dilaksanakan. ${ }^{6}$

\section{Epidemiologi KIPI}

Kejadian ikutan pasca imunisasi akan tampak setelah pemberian vaksin dalam dosis besar. Penelitian efikasi dan keamanan vaksin dihasilkan melalui fase uji klinis yang lazim, yaitu fase 1, 2, 3, dan 4. Uji klinis fase 1 dilakukan pada binatang percobaan, sedangkan fase selanjutnya dilakukan pada manusia. Fase 2 dan 3 untuk mengetahui seberapa jauh imunogenisitas dan keamanan (reactogenicity and safety) vaksin yang dilakukan pada jumlah yang terbatas. Pada jumlah dosis yang terbatas mungkin KIPI belum tampak, maka untuk menilai jumlah KIPI diperlukan penelitian uji klinis dalam jumlah sampel (orang, dosis vaksin) yang besar yang dikenal sebagai post marketing surveilance (PMS). ${ }^{4,6}$

Tujuan PMS ialah memonitor dan mengetahui keamanan vaksin setelah pemakaian yang cukup luas di masyarakat. Data PMS dapat memberikan keuntungan bagi program apabila semua KIPI (terutama KIPI berat) dilaporkan dan masalahnya 
Sari Pediatri, Vol. 2, No. 1, Juni 2000

Tabel 1. Gejala KIPI ${ }^{4}$

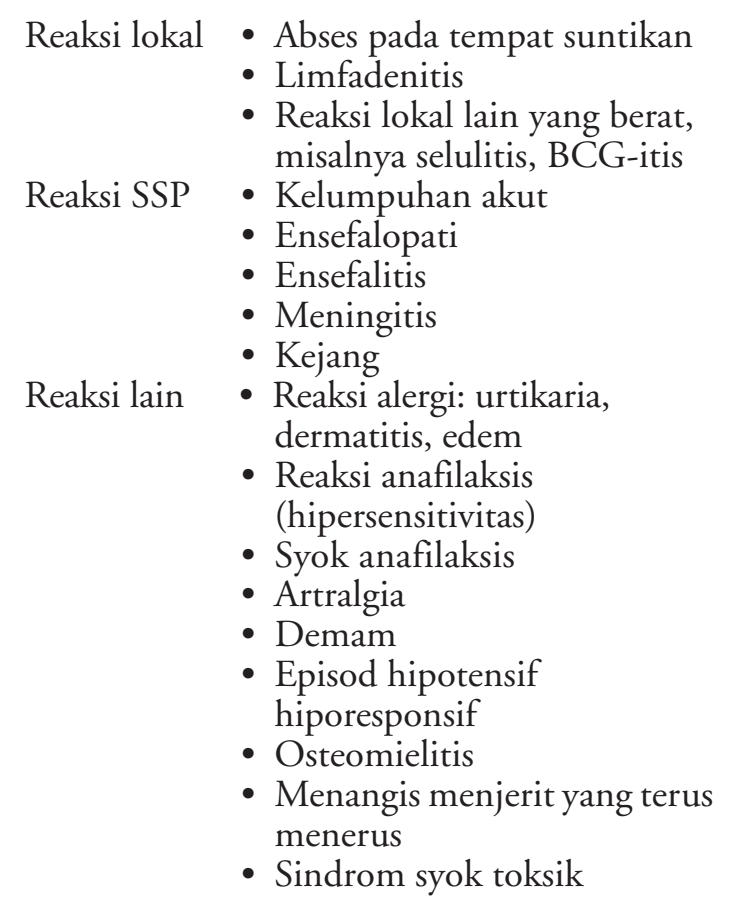

segera diselesaikan. Sebaliknya, akan merugikan apabila program tidak segera tanggap terhadap masalah KIPI yang timbul sehingga terjadi rumor di masyarakat mengenai efek samping vaksin dengan segala akibatnya.

Menurut Committee of the Institute of Medicine (IOM) dari National Childhood Vaccine Injury Amerika Serikat, kesulitan mendapatkan data KIPI, terjadi karena (1) kurang difahaminya mekanisme biologis gejala KIPI, (2) data kasus KIPI yang dilaporkan kurang rinci dan akurat, (3) surveilans KIPI belum luas dan menyeluruh (4) surveilans KIPI belum dilakukan untuk jangka panjang, (5) kurang publikasi KIPI dalam jumlah kasus yang besar. Mengingat hal-hal tersebut di atas, maka sangat sulit menentukan jumlah kasus KIPI yang sebenarnya. Kejadian ikutan pasca imunisasi dapat ringan sampai berat, terutama pada imunisasi massal atau setelah penggunaan lebih dari 10.000 dosis vaksin. ${ }^{8}$

\section{Gejala Klinis KIPI}

Gejala klinis KIPI dapat dibagi menjadi gejala lokal dan sistemik serta reaksi lainnya, dapat timbul secara cepat maupun lambat. Pada umumnya, makin cepat
KIPI terjadi makin berat gejalanya. Gejala klinis KIPI tertera pada Tabel 1 dan Tabel 2.

Standar keamanan suatu vaksin dituntut lebih tinggi daripada obat-obatan. Hal ini disebabkan oleh karena pada umumnya produk farmasi diperuntukkan orang sakit sedangkan vaksin untuk orang sehat terutama bayi. Akibatnya, toleransi terhadap efek samping vaksin harus lebih kecil daripada obat-obatan untuk orang sakit. Mengingat tidak ada satupun jenis vaksin yang aman tanpa efek samping, maka apabila seorang anak telah mendapat imunisasi perlu diobservasi beberapa saat, sehingga dipastikan bahwa tidak terjadi KIPI (reaksi cepat). Berapa lama observasi perlu dilakukan sebenarnya sulit ditentukan, tetapi pada umumnya setelah pemberian setiap jenis imunisasi harus dilakukan observasi paling sedikit selama 15 menit. ${ }^{6}$

Pada anak, KIPI yang paling serius adalah reaksi anafilaksis. Angka kejadian reaksi anafilaktoid diperkirakan 1 dalam 50.000 dosis DPT (whole cell pertussis), tetapi yang benar-benar anafilaksis hanya 1-3 kasus di antara 1 juta dosis. Anak besar dan dewasa lebih banyak mengalami sinkope, segera atau lambat. Episod hipotonik hiporesponsif juga tidak jarang terjadi, secara umum dapat terjadi 4-24 jam setelah imunisasi.

\section{Tatalaksana KIPI}

Tatalaksana KIPI pada dasarnya terdiri dari penemuan kasus, pelacakan kasus lebih lanjut, analisis kejadian, tindak lanjut kasus, dan evaluasi, seperti tertera pada Gambar 2. Dalam waktu 24 jam setelah penemuan kasus KIPI yang dilaporkan oleh orang tua (masyarakat) ataupun petugas kesehatan, maka pelacakan kasus harus segera dikerjakan. Pelacakan perlu dilakukan untuk konfirmasi apakah informasi yang disampaikan tersebut benar. Apabila memang kasus yang dilaporkan diduga KIPI, maka dicatat identitas kasus, data vaksin (jenis, pabrik, nomor batchlot), petugas yang melakukan, dan bagaimana sikap masyarakat saat menghadapi masalah tersebut. Selanjutnya perlu dilacak kemungkinan terdapat kasus lain yang sama, terutama yang mendapat imunisasi dari tempat yang sama dan jenis lot vaksin yang sama. Pelacakan dapat dilakukan oleh petugas Puskesmas atau petugas kesehatan lain yang bersangkutan. Sisa vaksin (apabila masih ada) yang diduga menyebabkan KIPI harus disimpan sebagaimana kita memperlakukan 
Tabel 2. Gejala KIPI menurut jenis vaksin dan saat timbulnya. ${ }^{4}$

\begin{tabular}{|c|c|c|}
\hline Jenis Vaksin & Gejala Klinis KIPI & Saat timbul KIPI \\
\hline Toksoid (DPT, DT, TT) & $\begin{array}{l}\text { a. Syok anafilaksis } \\
\text { b. Neuritis brakial } \\
\text { c. Komplikasi akut termasuk } \\
\text { kecacatan dan kematian }\end{array}$ & $\begin{array}{l}4 \text { jam } \\
2-28 \text { hari } \\
\text { tidak tercatat }\end{array}$ \\
\hline Pertusis whole-cell (DPT, DTP-HB) & $\begin{array}{l}\text { a. Syok anafilaksis } \\
\text { b. Ensefalopati } \\
\text { c. Komplikasi akut termasuk } \\
\text { kecacatan dan kematian }\end{array}$ & $\begin{array}{l}4 \text { jam } \\
72 \text { jam } \\
\text { tidak tercatat }\end{array}$ \\
\hline $\begin{array}{l}\text { Campak, gondongan, rubela (MMR atau } \\
\text { salah satu komponen) }\end{array}$ & $\begin{array}{l}\text { a. Syok anafilaksis } \\
\text { b. Ensefalopati } \\
\text { c. Komplikasi akut termasuk } \\
\text { kecacatan dan kematian }\end{array}$ & $\begin{array}{l}4 \text { jam } \\
5-15 \text { hari } \\
\text { tidak tercatat }\end{array}$ \\
\hline Rubela & $\begin{array}{l}\text { a. Artritis } \\
\text { b. Komplikasi akut termasuk } \\
\text { kecacatan dan kematian }\end{array}$ & $\begin{array}{l}7-42 \text { hari } \\
\text { tidak tercatat }\end{array}$ \\
\hline Campak & $\begin{array}{l}\text { a. Trombositopenia } \\
\text { b. Klinis campak pada resipien } \\
\text { imunokompromais } \\
\text { c. Komplikasi akut termasuk } \\
\text { kecacatan dan kematian }\end{array}$ & $\begin{array}{l}7-30 \text { hari } \\
6 \text { bulan } \\
\text { tidak tercatat }\end{array}$ \\
\hline Polio hidup (OPV) & $\begin{array}{l}\text { a. Polio paralisis } \\
\text { b. Polio paralisis pada resipien } \\
\text { imunokompromais } \\
\text { c. Komplikasi akut termasuk } \\
\text { kecacatan dan kematian }\end{array}$ & $\begin{array}{l}30 \text { hari } \\
6 \text { bulan } \\
\text { tidak tercatat }\end{array}$ \\
\hline Vaksin berisi polio yang diinaktifasi (IPV) & $\begin{array}{l}\text { a. Syok anafilaksis } \\
\text { b. Komplikasi akut termasuk } \\
\text { kecacatan dan kematian }\end{array}$ & $\begin{array}{l}4 \text { jam } \\
\text { tidak tercatat }\end{array}$ \\
\hline Hepatitis B & $\begin{array}{l}\text { a. Syok anafilaksis } \\
\text { b. Komplikasi akut termasuk } \\
\text { kecacatan dan kematian }\end{array}$ & $\begin{array}{l}4 \text { jam } \\
\text { tidak tercatat }\end{array}$ \\
\hline $\begin{array}{l}\text { Haemophilus influenzae tipe b } \\
\text { (unconjugated, PRP) }\end{array}$ & $\begin{array}{l}\text { a. Klinis infeksi Hib } \\
\text { b. Komplikasi akut termasuk } \\
\text { kecacatan dan kematian }\end{array}$ & 7 hari \\
\hline
\end{tabular}

vaksin pada umumnya (perhatikan cold chain).

Kepala Puskesmas atau Pokja KIPI daerah dapat menganalisis data hasil pelacakan untuk menilai klasifikasi KIPI dan dicoba untuk mencari penyebab KIPI tersebut. Dengan adanya data kasus KIPI dokter Puskesmas dapat memberikan pengobatan segera. Apabila kasus tergolong berat, penderita harus segera dirawat untuk pemeriksaan lebih lanjut dan diberikan pengobatan segera. Evaluasi akan dilakukan oleh Pokja KIPI setelah menerima laporan. Pada kasus ringan tatalaksana dapat diselesaikan oleh Puskesmas dan Pokja KIPI hanya perlu diberikan laporan. Untuk kasus berat yang masih dirawat, sembuh dengan gejala sisa, atau kasus meninggal, diperlukan evaluasi ketat dan apabila diperlukan Pokja KIPI segera dilibatkan. Evaluasi akhir dan kesimpulan disampaikan kepada Kepala Puskesmas untuk perbaikan program yang akan datang.

\section{Pencatatan dan Pelaporan}

Pada pelaksanaannya, penyebab KIPI tidaklah mudah ditentukan. Untuk menentukan penyebab KIPI diperlukan keterangan rinci mengenai riwayat 


\section{Penemuan Kasus}

$$
\downarrow 24 \mathrm{jam}
$$

\section{Pelacakan}

(1) Konfirmasi : positif atau negatif

(2) Identifikasi : Data kasus

Vaksin

Petugas

Tatalaksana

Sikap masyarakat

(3) Tunggal/berkelompok

(4) Apakah ada kasus lain

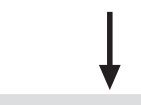

\section{Analisis \\ (1) Klasifikasi \\ (2) Penyebab

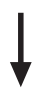

\section{Tindak Lanjut \\ (1) Pengobatan \\ (2) Komunikasi \\ (3) Perbaikan mutu pelayanan}

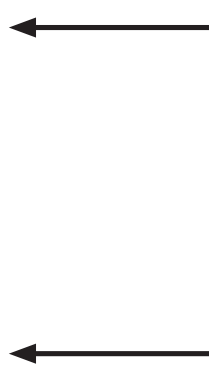

\section{Puskesmas}

Kepala

Puskesmas/

Pokja KIPI

Petugas

Puskesmas

Masyarakat atau

Petugas kesehatan

\section{Pokja KIPI}

\section{$\downarrow$}

\section{Evaluasi \\ (1) Tatalaksana kasus \\ (2) Pemantauan KIPI}

\section{Pokja KIPI}

Gambar 2. Alur tatalaksana KIPI ${ }^{9}$

pemberian vaksin terdahulu, adakah ditemukan alternatif penyebab, kerentanan individu terhadap vaksin, kapan KIPI terjadi (tanggal, hari, jam), bagaimana gejala yang timbul, berapa lama interval waktu sejak diberi vaksin sampai timbul gejala, apakah dilakukan pemeriksaan fisis serta ditunjang dengan pemeriksaan laboratorium, serta pengobatan apa yang telah diberikan. Dari data yang tersedia kemudian diperlukan analisis kasus untuk mengambil kesimpulan. Daftar KIPI yang harus dilaporkan tertera pada Tabel 3.

Hal-hal yang perlu mendapat perhatian pada pelaporan.

1. Identitas: Nama anak, tanggal dan tahun lahir (umur), jenis kelamin, nama orang tua, dan alamat.

2. Jenis vaksin yang diberikan, dosis, nomer lot, siapa yang memberikan. Vaksin sisa disimpan dan 


\section{Menteri Kesehatan}<smiles>CCCCC</smiles>

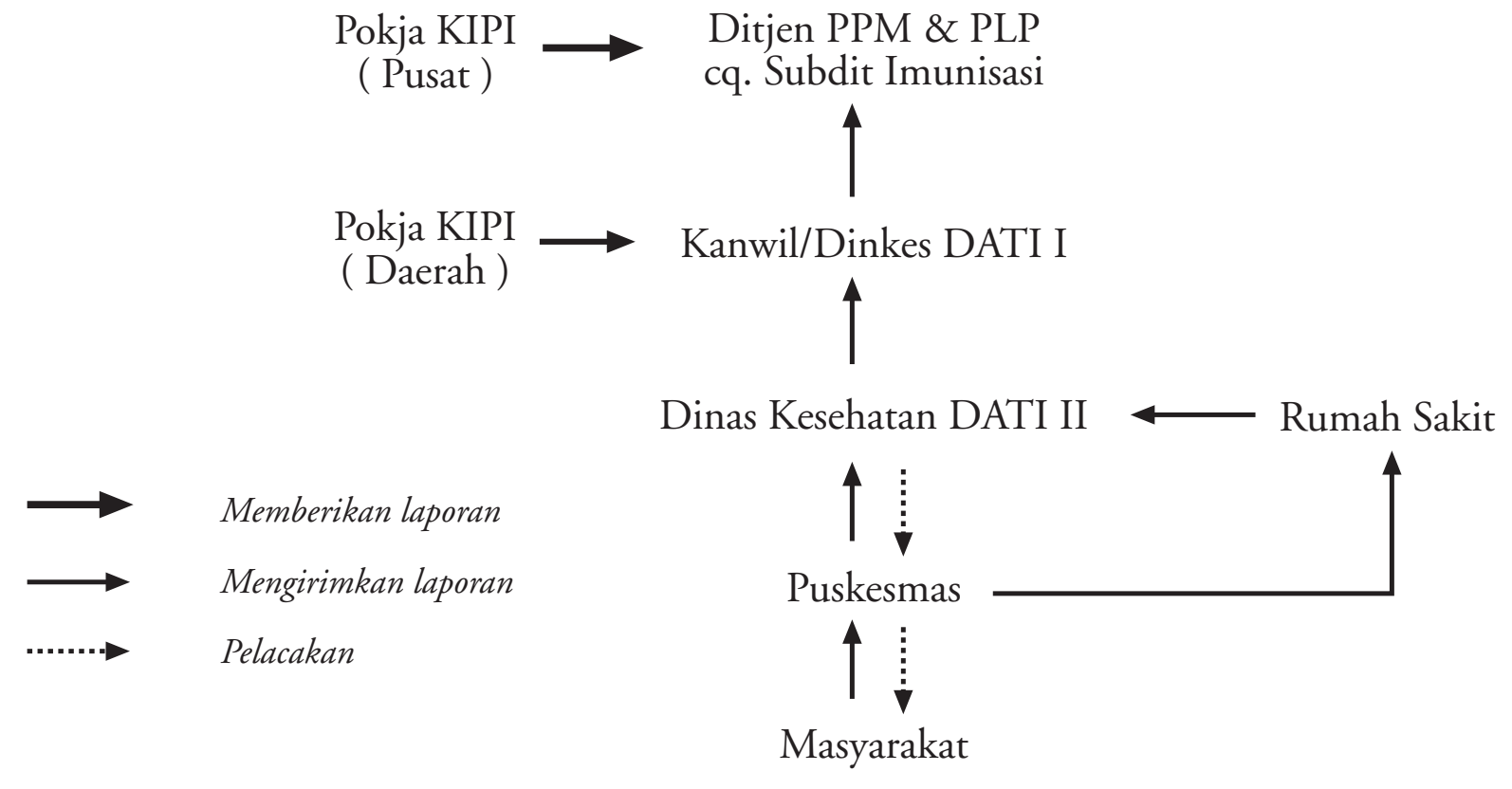

Gambar 3. Alur Pelaporan dan Pelacakan KIPI

diperlakukan seperti vaksin yang masih utuh (perhatikan cold chain).

3. Nama dokter yang bertanggung jawab

4. Apakah pernah menderita KIPI pada imunisasi terdahulu?

5. Gejala klinis yang timbul dan/atau diagnosis (bila ada); tulis dalam kolom laporan yang tersedia. Pengobatan yang diberikan dan perjalanan penyakit, sembuh, dirawat atau meninggal. Sertakan hasil laboratorium yang pernah dilakukan. Tulis juga apabila terdapat penyakit lain yang menyertainya.

6. Waktu pemberian imunisasi, tanggal, jam.

7. Saat timbulnya gejala KIPI sehingga diketahui berapa lama interval waktu antara pemberian imunisasi dengan terjadinya KIPI.

8. Apabila dirawat dan sembuh, apakah terdapat gejala sisa?

9. Bagaimana cara menyelesaikan masalah KIPI (kronologis)

10. Adakah tuntutan dari keluarga?
Tabel 3. KIPI yang harus dilaporkan. ${ }^{1,5}$

KIPI terjadi dalam waktu 48 jam setelah imunisasi (satu gejala atau lebih)

- Anafilaksis

- Syok

- Episod hipotonik hiporesponsif

KIPI terjadi dalam waktu 30 hari setelah imunisasi (satu gejala atau lebih)

- Ensefalopati

- Kejang

- Meningitis aseptik

- Trombositopenia

- Lumpuh layu (acute flaccid paralysis)

- Meninggal

- Penyebab lain yang berat termasuk bila anak perlu perawatan 
Reaksi KIPI dapat dipantau melalui sistem surveilans yang baik untuk mendapatkan profil keamanan penggunaan di lapangan. Untuk mengetahui besarnya masalah KIPI di Indonesia diperlukan pelaporan dan pencatatan kasus KIPI dan koordinasi antara pengambil keputusan dengan petugas pelaksana di lapangan, guna menentukan sikap dalam mengatasi kasus KIPI yang terjadi. Dalam rangka meningkatkan kegiatan diperlukan pelaporan dan pencatatan kasus KIPI untuk mengkoordinasikan hal tersebut, telah dibentuk Pokja KIPI Depkes yang terdiri dari klinisi, organisasi profesi (IDAI, POGI), pakar dalam bidang mikrobiologi, virologi, vaksin, farmakologi, epidemiologi, dan pakar hukum. Pokja KIPI dalam kegiatannya bekerja sama dengan Subdit Imunisasi Direktorat Jendral PPM\&PLP Departemen Kesehatan. Risiko KIPI selalu ada pada setiap tindakan imunisasi, oleh karena itu profesi kesehatan yang terkait perlu memahami KIPI serta penanggulangannya. Pokja KIPI diharapkan juga dapat dibentuk di daerah Dati I guna menjalin kerjasama antara para pakar terkait, instansi kesehatan, dan pemerintah daerah setempat.

\section{Imunisasi pada kelompok berisiko}

Untuk mengurangi risiko timbulnya KIPI, harus diperhatikan apakah resipien termasuk dalam kelompok berisiko, yaitu: ${ }^{10}$

1. Anak yang pernah mendapat reaksi vaksinasi yang tidak diinginkan harus segera dilaporkan kepada Pokja KIPI daerah untuk penanganan segera dan Pokja KIPI pusat dengan mempergunakan formulir pelaporan yang telah tersedia.

2. Bayi berat lahir rendah. Pada dasarnya jadwal imunisasi bayi kurang bulan sama dengan bayi cukup bulan. Hal-hal yang perlu diperhatikan pada bayi kurang bulan adalah (1) titer imunitas pasif melalui transmisi maternal lebih rendah daripada bayi cukup bulan, (2) apabila berat badan bayi sangat kecil (<1000 gram), imunisasi ditunda dan diberikan apabila bayi telah mencapai berat 2000 gram atau bayi berumur 2 bulan, (3) imunisasi hepatitis B diberikan pada umur 2 bulan atau lebih, kecuali apabila diketahui ibu mengandung $\mathrm{HbsAg}$, dan (4) apabila bayi masih dirawat setelah umur 2 bulan, maka vaksin polio diberikan secara suntikan (IPV) sehingga tidak menyebabkan penyebaran virus polio melalui tinja.

3. Pasien imunokompromais. Keadaan imunokompromais dapat terjadi sebagai akibat penyakit dasar atau sebagai akibat pengobatan (pengobatan kemoterapi, kortikosteroid jangka panjang). Vaksinasi dengan mempergunakan vaksin hidup merupakan indikasi kontra pada pasien imuno-kompromais. Imunisasi tetap diberikan pada pengobatan kortikosteroid dosis kecil dan dalam waktu pendek. Pada anak dengan pengobatan kortikosteroid sistemik dosis $2 \mathrm{mg} / \mathrm{kg}$ berat badan/hari atau prednison $20 \mathrm{mg} /$ hari selama 14 hari, maka imunisasi ditunda. Imunisasi dapat diberikan setelah 1 bulan pengobatan kortikosteroid dihentikan, atau 3 bulan setelah kemoterapi selesai.

4. Pada resipien yang mendapatkan human immunoglobulin, imunisasi virus hidup diberikan setelah 3 bulan pengobatan untuk menghindarkan hambatan pembentukan respons imun.

Himbauan WHO terhadap pemantauan KIPI tertuang pada pertemuan WHO-SEARO tahun 1996 yang merekomendasikan bahwa: ${ }^{6}$

1. Program pengembangan imunisasi (PPI) harus mempunyai perencanaan rinci dan terarah sehingga dapat memberikan tanggapan segera pada laporan KIPI.

2. Setiap KIPI berat harus dilakukan pemeriksaan oleh tim yang terdiri dari para ahli epidemiologi dan profesi (di Indonesia Pokja KIPI) dan penemuan harus disebarluaskan melalui jalur PPI dan media masa.

3. Program harus segera memberikan tanggapan secara cepat dan akurat kepada media massa perihal KIPI yang terjadi.

4. Pelaporan KIPI tertentu misalnya abses, BCG-itis, harus dipantau demi perbaikan cara penyuntikan yang benar di kemudian hari.

5. Program harus melengkapi petugas lapangan dengan formulir pelaporan kasus, definisi KIPI yang jelas, instruksi yang rinci perihal jalur pelaporan.

6. Program perlu mengkaji laporan kasus KIPI dari pengalaman dunia internasional, sehingga dapat memperkirakan besar masalah KIPI yang dihadapi. 


\section{Kesimpulan}

Imunisasi sebagai upaya pencegahan penyakit infeksi yang paling efektif untuk meningkatkan mutu kesehatan masyarakat akan diikuti dengan pemakaian vaksin dalam dosis besar. Seiring dengan penggunaan vaksin secara masal, kejadian ikutan pasca imunisasi akan semakin kerap dijumpai. Kewaspadaan dan ketelitian dalam melaksanakan imunisasi akan mengurangi KIPI yang terjadi. Penanganan segera disertai pelaporan dan pencatatan kasus KIPI akan sangat berguna dalam memperbaiki pelaksanan program imunisasi dan meningkatkan kepercayaan masyarakat terhadap manfaat imunisasi di negara kita.

\section{Daftar Pustaka}

1. Kassianos GC, penyunting. Immunization Childhood and Trame Health. Edisi ketiga. London: Blackwell Science, 1996.

2. World Health Organization Children Vaccine Initiative.
Strategic planning. Managing opportunity of change a vision of vaccination for the $21^{\text {th }}$ century. Geneva: Children's Vaccine Initiative-WHO, 1997.

3. Watson C, penyunting. National Immunisation Program: The Australian Immunisation Handbook. Edisi ke-6. Commonwealth of Australia: National Health and Medical Research Council 1997.

4. Chen RT. Safety of vaccines. Dalam: Plotkin SA, Mortimer WA, penyunting. Vaccines. Edisi ketiga. Philadelphia, Tokyo: WB Saunders, 1999:1144-57.

5. Stratton KR, Howe CJ, Johnston RB. Adverse events associated with childhood vaccines. Evidence bearing on causality. Washington DC: National Academy Press, 1994.

6. World Health Organization. Surveillance of adverse events following immunization. Field guide for managers of immunization programmes. Geneva: WHO, 1997.

7. Conference Review. Vaccine today protecting the future. Kuala Lumpur, 18-19 March 1998.

8. Subdit Imunisasi Ditjen PPM\&PLP Departemen Kesehatan. Petunjuk teknis KIPI. Jakarta: Ditjen PPM\&PLP Departemen Kesehatan, 1998.

9. Henderson RH. Vaccination: Success and Challenges. Dalam: Cutt FT, Smith PG, Penyunting. Vaccination \& World Health Chichester, Singapura: John Wiley \& Sons, 1994:3-16. 